\title{
Transportes Transportation
}

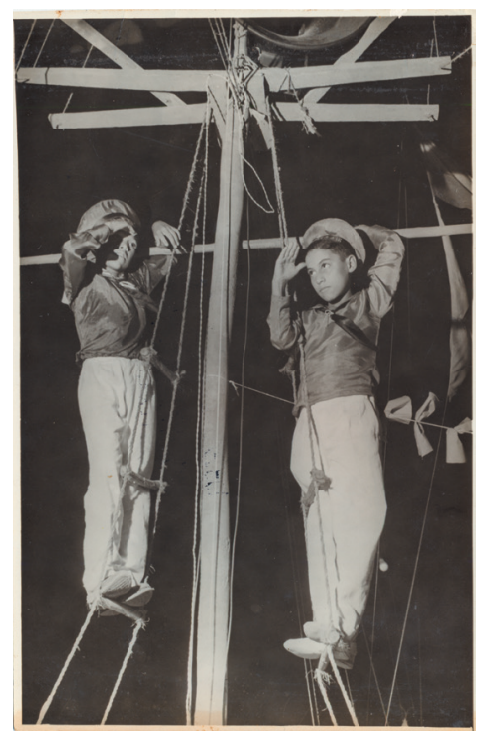

Fandango, [S.d.]

Fandango dance, [undated] 


\title{
Transportation
}

\author{
Maisa Sales Gama Tobias ${ }^{1}$
}

The evolution of the transportation systems is one important chapter of the world history of technological changes. The innovation represented by the development of transportation means has received special attention by economic historians, particularly the revolution brought by vapor-driven transportation throughout the 19th century, such as merchant ships and, mainly, railways. The transportation systems have always played a strategic role in the socio-economic development of countries, especially the capitalist ones. Therefore, understanding data on the evolution of the transportation system is to envision the process of society development itself, since every country needs an efficient transportation system, suitable to the development of their territories. Transportation flows are grouped in modal networks, through nodes and links, and their interconnection is a crucial element for a country's development. This chapter portrays and discusses the recent evolution of the Brazilian transportation sector, presenting its current status, based on consolidated information produced by the Brazilian Institute of Geography and Statistics (IBGE), as shown in the tables and graphs complementing the text. At the end, some considerations are proposed so that the transportation system can fulfill its role in the process of economic and social development of Brazil.

$\overline{1 \mathrm{PhD}}$ in Transportation Engineering from the Polytechnic School of the University of São Paulo (POLI/USP). Full professor at the Civil Engineering School, Institute of Technology of the Federal University of Pará (FEC/ITEC/UFPA) and Coordinator of the Center of Territorial Mobility and Sustainable Development in Amazon. 


\title{
Transportes
}

\author{
Maisa Sales Gama Tobias ${ }^{1}$
}

A evolução dos sistemas de transportes constitui um capítulo importante da história mundial das mudanças tecnológicas. A inovação representada pelo desenvolvimento dos meios de transportes tem recebido expressiva atenção por parte dos historiadores econômicos, em especial a revolução protagonizada pelos transportes movidos a vapor ao longo do Século XIX, como a navegação mercante e, principalmente, as estradas de ferro. Os sistemas de transportes sempre foram elementos estratégicos no processo de desenvolvimento econômico social dos países, principalmente, para o sistema capitalista. Portanto, entender os dados sobre a evolução dos sistemas de transporte é vislumbrar o próprio processo de evolução do desenvolvimento da sociedade, pois todo país precisa de um sistema de transporte eficiente e adequado às condições de seu território para desenvolver-se. Os fluxos de transporte articulam-se em redes modais, através de arcos e nós, e a sua capacidade de interligação é determinante sobre a capacidade de desenvolvimento de um país. Este capítulo retrata e analisa dados recentes da evolução do setor de transportes brasileiro, apresentando o quadro atual, partindo de informações consolidadas pelo Instituto Brasileiro de Geografia e Estatística (IBGE), conforme tabelas e gráficos apresentados em complemento ao texto, encerrando com considerações a respeito de intervenções para que os sistemas de transportes possam

1 Doutora em Engenharia de Transportes pela Escola Politécnica da Universidade de São Paulo (POLI/USP). Professora Titular da Faculdade de Engenharia Civil, Insituto de Tecnologia da Universidade Federal do Pará (FEC/ITEC/UFPA) e Coordenadora do Núcleo de Mobilidade Territorial e Desenvolvimento Sustentável na Amazônia. 


\section{Infrastructure and matrix of transportation in Brazil}

The evolution of the infrastructure and of the matrix of transportation in Brazil followed the country's own political growth and development, being in line with the public policies for the sector. First, there was the waterway transportation and, after that, the railways were implemented, in the initial colonization centuries, and, finally, given the big size of the territory, there was the late insertion of the road transportation, crucial for the achievement and consolidation of our sovereignty. The statistical behavior of the transportation data reflects and contributes to the assessment of public actions and policies carried out in the country and to the planning of the next steps. It represents a necessary accountability of the resources, their allocation to the modes and a portrait of the deficiencies to overcome.

Table 15.1 presents the extension of the transportation networks in Brazil, for each mode. There we can see the prevalence of the roadway mode, whose great majority belongs to states and municipalities and is unpaved. The railway and waterway networks come in second place, far below the extension of the roadway modality. Such data point out that, comparing the current transportation network and the share of it which is actually used, the railway is fully exploited, whereas the waterway is underused.

Graph 15.1 presents the freight transportation mode in Brazil. There we can see the prevalence of the roadway mode, with more than $61 \%$ of freight transportation (tonne-kilometer-tkm) being used by this mode, whereas the railway transportation covers $20.7 \%$ and waterway transportation, $13.6 \%$. In a very much lower proportion, air transportation together with pipeline transportation represent less than $5.0 \%$. It is worth highlighting that the country presents its mode matrix with prevalence of the roadway transportation, either freight or passenger, which results in an impact on the logistics costs, directly influencing the prices of Brazilian services and goods. Such prevalence of the roadway transportation in the urban area also affects the environment, with the emission of pollutants compromising the health of citizens and contributing to the emergence of diseases of the respiratory, cardiovascular, neurological and dermatological systems.

Data show a need that has remained the same throughout the years: to enhance the participation of the other modes in the matrix, establishing a balance in the allocation of public resources in infrastructure, encouraging private investment by means of partnerships. Moreover, redirecting freight and passenger flows to less expensive transportation solutions, even when initial costs are higher, is preparing the country for 
desempenhar de maneira favorável o seu papel no processo de desenvolvimento econômico e social do Brasil.

\section{Infraestrutura e matriz dos transportes no Brasil}

A evolução da infraestrura e da matriz de transportes no Brasil seguiu em paralelo ao seu próprio crescimento e desenvolvimento político e alinhada às políticas públicas para o setor. Assim, tem-se a chegada do transporte aquaviário, seguida do ferroviário, nos séculos iniciais de colonização e, diante de um território tão vasto, a inserção posterior do transporte rodoviário para a conquista e demarcação de soberania. O comportamento estatístico dos dados de transportes reflete e contribui para a avaliação das ações e das políticas públicas implementadas no País e para o planejamento dos próximos passos. Uma prestação de contas necessária para a população de como os recursos estão sendo empregados, sua distribuição entre os modos e as deficiências a serem corrigidas.

A Tabela 15.1 apresenta a extensão das malhas viárias do Brasil, para cada modalidade. Nela se verifica predominância do modo rodoviário, sendo em grande parte de jurisdição de estados e municípios e não pavimentadas. As malhas ferroviária e hidroviária apresentam-se em segundo plano, numa extensão bem abaixo do modal rodoviário. Tais dados evidenciam que na relação da malha viária existente e a de fato utilizada, há o pleno uso da malha ferroviária e o subaproveitamento da malha hidroviária.

O Gráfico 15.1 apresenta a divisão modal do transporte de cargas no Brasil. Nele se verifica predominância do modo rodoviário, com mais de $61 \%$ do momento de transporte (tonelada por quilômetro útil - TKU) sendo realizado por este modo, enquanto o transporte ferroviário de $20,7 \%$ e o transporte aquaviário, de $13,6 \%$. Em proporção bem menor, o transporte aéreo e dutoviário somados não chegam a representar 5,0\%. Vale ressaltar que o País apresenta a sua matriz de divisão modal com a predominância do transporte rodoviário, seja para cargas e passageiros, o que tem como consequência um impacto nos custos logísticos, incidindo diretamente nos preços dos produtos e serviços brasileiros. Esta predominância do transporte rodoviário sobre o espaço urbano, impacta também o meio ambiente, com a emissão de poluentes atmosféricos, comprometendo a saúde dos cidadãos e contribuindo para o aparecimento de doenças do sistema respiratório, cardiovascular, neurológicas e dermatológicas.

Os dados mostram uma necessidade que se mantém ao longo dos anos, que é de ampliar a participação dos outros modos de transporte na matriz de divisão mo- 
a more productive and competitive future, both in terms of economy and quality of life in the cities.

\section{Operation of railway transportation in Brazil}

In Table 15.2, it is clear that railways are operated through 12 concessionaires, of which three hold $89.9 \%$ of the railways with the highest tkms, calculated multiplying the net freight transported (tonnes) by the distance traveled (km). They are: Carajás Railway (EFC) (47.3\%), Vitória-Minas Railway (EFVM) (24.4\%) and MRS Logística S.A. (18.15\%). It should be highlighted that the concessionaires have ore as their main transported cargo, especially because railway transportation with bulk material is more effective both in terms of cost $(R \$ / \mathrm{tkm})$ and energy use in megajoules per tonne-kilometer ( $\mathrm{MJ} / \mathrm{tkm})$.

\section{Level of individual motorization in Brazil in relation to other countries}

The individual motorization in developed countries was stable between 2001 and 2015, below two inhabitants per vehicle, as it can be seen in Graph 15.2 for countries such as the United States, United Kingdom, Italy, Japan, German and France. As a matter of fact, the USA and France remained unchanged throughout those years and the others had small changes here and there.

Brazil and Mexico, two of the most populous countries in the world, stand out for the motorization levels of 8.6 and 6.1 inhabitants per vehicle, respectively, between 2001 and 2015. However, between 2001 and 2011, Mexico had a sharp decrease to 3.6 inhabitants per vehicle and got stable up to 2015 with nearly 3.5 inhabitants per vehicle, whereas Brazil, within a decade (2001 and 2011), fell to 5.7 inhabitants per vehicle and, in the following years, went down in a curve of less intensity. In 2015, it reached 4.7 inhabitants per vehicle. Of all countries portrayed in Graph 15.2, Brazil shows the smallest drop in the level of motorization.

Moreover, it is worth highlighting that in the beginning of this century, with the economic growth and increase of the purchasing power of the Brazilian population, together with the incentives given by the government to the car industry between 2012 and 2014 - reduction of the Tax on Industrialized Goods (IPI) -, the acquisition of vehicles increased and, as a consequence, the fleet of cars and light commercial vehicles rose. Although this phase came to an end with the economy downturn, present days still suffer from the effects of those times in the urban areas: traffic jams in big cities and the need for maintenance works in the transportation network. 
dal, reequilibrando a aplicação de recursos públicos em infraestrutura, estimulando também investimentos do setor privado, através de parcerias. Redirecionar fluxos de carga e passageiros para as situações de transporte de menor custo operacional, mesmo que de investimentos iniciais mais altos, é preparar o País para um futuro mais produtivo e competitivo economicamente e de melhor qualidade de vida nas cidades.

\section{A operação do transporte ferroviário no Brasil}

Na Tabela 15.2 verifica-se que a operação do transporte ferroviário se dá por 12 concessionárias, sendo que três delas detêm $89,9 \%$ de maior TKU, cuja medida é definida pelo produto da carga líquida transportada (tonelada) pela distância percorrida $(\mathrm{km})$, são elas: Estrada de Ferro Carajás (EFC) (47,3\%), Estrada de Ferro Vitória a Minas (EFVM) $(24,4 \%)$ e a MRS Logística S.A. (18,15\%). Ressalta-se, que estas concessionárias têm como principal carga movimentada o minério, até pelo fato do transporte ferroviário ser para granéis mais eficiente em termos de custo (R\$/TKU) e uso de energia em megajoules por tonelada-quilômetro ( $\mathrm{MJ} / \mathrm{t} . \mathrm{km})$.

\section{O grau de motorização individual do Brasil em relação aos outros países}

A motorização individual nos países desenvolvidos tem-se mostrado estável entre 2001 e 2015, abaixo de dois habitantes por veículo, como pode ser visto no Gráfico 15.2 para países como Estados Unidos, Reino Unido, Itália, Japão, Alemanha e França. Inclusive, os Estados Unidos e a França sem variação alguma ao longo desses anos e os demais com pequenas variáveis em um ou outro ano.

O Brasil e o México, dois dos países mais populosos do mundo, se destacam pelos graus de motorização de 8,6 e 6,1 habitantes por veículo, respectivamente, entre 2001 e 2015. No entanto, entre 2001 e 2011, o México tem uma queda acentuada para 3,6 habitantes por veículo e se estabiliza até 2015 em torno de 3,5 habitantes por veículo, enquanto que o Brasil em uma década (2001 a 2011) cai para 5,7 habitantes por veículo e, nos anos seguintes, numa curva descendente de menor gradiente, em 2015 chega a 4,7 habitantes por veículo. De todos os países apresentados no Gráfico 15.2 é o de menor queda no grau de motorização.

Sobre o Brasil, vale destacar que no início deste século, com o crescimento econômico e aumento do poder aquisitivo da população, atrelado aos incentivos dados pelo governo à indústria automobilística entre 2012 e 2014, por meio da redução da alíquota do Imposto Sobre Produtos Industrializados (IPI), propiciou a aquisição de veículos e, consequemente, o aumento da frota de automóveis e veículos co- 


\section{Flow of waterway freight transportation in Brazil}

The extension of the waterway network corresponds to $2.5 \%$ of the roadway network in Brazil, with a total of $41,795 \mathrm{~km}$, of which nearly $47 \%$ are economically exploited (Table 15.1). There are several reasons for that, linked to the sinuosity of rivers, low drafts, but it also relates to the lack of mode-integration policies for the country's waterways based on a multimodal view of how to take better advantage of the potentiality of the waterway resources, especially in the North Region.

Waterway freight transportation takes place basically through longterm navigation, cabotage navigation, beside others. In the last decade, long-term navigation had some sporadic peaks, every three years, as we can see in Table 15.3, having decreased in 2019. The flow of cabotage navigation grew increasingly from 2011 to 2019. That occurred more rapidly with other navigation modes, but with less significant figures in relation to the total hauled cargo.

The growth curves can be seen in Graph 15.3, where the navigation in lower and more stable levels of growth are cabotage and other modes of navigation. The highlight is long-term navigation, significantly rising along the years, with a slight decrease in 2019.

\section{Air transportation evolution in Brazil}

Air transportation in Brazil is divided into international and domestic. Graph 15.4 presents the number of international flights between 2010 and 2019 as a stable figure; the same does not go for domestic flights, whose peak was in 2012 and, from there on, decreased 20\% up to 2019. The annual percentage contribution of international and domestic flights was stable along the years. The flow of flights from 2010 to 2019 boosts in 2012 (above 1.1 million flights), with a slight decrease from 2013 to 2015 and decreasing to reach 900 thousand flights from 2016 onwards and, in 2019, still decreasing, mainly in terms of domestic flights. International flights, however, presented a growth of 43\% (2009-2014), followed by drops in 2016 and 2017, with the worst performance in the latter, regaining better results in 2018 and 2019 (average increase of 11\%).

For a broader understanding of the sector's evolution, it is important to verify the number of passengers and volume of cargo transported. Graph 15.5 presents these data and allows us to see that the growth in the number of passengers is similar to the growth in the number of flights from 2010 to 2012; in contrast, from 2013 on, when there was a retraction in the flight supply, as shown in Graph 15.4, the number of passengers went on increasing until 2015 to fall in 2016. There was also a recovery 
merciais leves. Apesar desta fase ter passado, com o desaquecimento da economia, porém, esse cenário recente ainda repercute nos dias atuais em situações urbanas, como os congestionamentos no trânsito dos grandes centros urbanos e na necessidade de manutenção da malha viária.

\section{A movimentação do transporte aquaviário de cargas no Brasil}

A extensão da malha hidroviária corresponde a 2,5\% da malha rodoviária do Brasil, com total de $41795 \mathrm{~km}$, onde aproximadamente 47\% são utilizadas economicamente (Tabela 15.1). Há diversas razões para isto, ligadas à própria sinuosidade dos rios, baixo calado, porém, também ligadas à falta de uma política hidroviária para o País e que trate de maneira integrada, dentro de uma visão multimodal o aproveitamento da potencialidade dos recursos hídricos, principalmente, na Região Norte.

O transporte aquaviário de cargas se movimenta basicamente por navegação de longo curso, de cabotagem, além de outros tipos. Ao longo da última década, na navegação de longo curso houve momentos de saltos, de três em três anos, como pode ser visto na Tabela 15.3, tendo descrecido em 2019. A movimentação na navegação de cabotagem vem crescendo de 2011 a 2019. O que ocorre de maneira mais acelerada por outros tipos de navegação, porém em montantes menos expressivos em relação à carga total movimentada.

As curvas de crescimento podem ser observadas no Gráfico 15.3, onde se tem em patamares mais baixos e estáveis de crescimento a navegação de cabotagem e por outros tipos de navegação, se destacando a navegação de longo curso, de maneira expressiva e ascendente ao longo dos anos, com ligeira queda em 2019.

\section{A evolução do transporte aéreo no Brasil}

O transporte aéreo no Brasil se divide em internacional e doméstico. O Gráfico 15.4 apresenta o número de voos internacionais entre os anos de 2010 e 2019 de maneira estável; o mesmo não ocorrendo com os voos domésticos, cujo pico foi em 2012 e, daí em diante, decaindo em $20 \%$ até 2019. Anualmente, a contribuição percentual entre voos internacionais e domésticos se mantém estável ao longo dos anos. Analisando a movimentação de voos de 2010 a 2019, o pico do voos ocorreu em 2012 (acima de um milhão e cem mil voos), com ligeira queda entre os anos de 2013 a 2015, e a partir de 2016 decaindo para patamares em torno de 900 mil voos, e, em 2019 , se manifesta em queda, principalmente de voos domésticos. Diferentemente dos voos domésticos, os voos internacionais apresentaram um crescimento de $43 \%$ 
of the demand, which gradually increased in 2017, 2018 and 2019, both in domestic flights and in international ones, with decongestion of air traffic, improving the business environment of big city centers and the quality of life of their residents.

As to the air freight flow, Graph 15.6 presents a similar pattern to that of Graph 15.4 in terms of general flight supply. However, the prevalence of the cargo demand is much higher for international flights, with the domestic demand standing quite stable, decreasing in the years of greater retraction of air cargo, in 2016.

It is noticeable that freight transportation, in terms of general behavior of curve fluctuation, is much more similar to the behavior of the flight supply curve; but in terms of typification of flight supply, whether domestic or international, the evolution of passengers taken is more similar to the flight supply, with a prevailing international demand in the case of air cargo.

\section{Final remarks}

The transportation systems have always played a strategic role in the socio-economic development of countries. Therefore, their indicators are important for the analysis of the very process of development and the planning of public actions and policies. The first piece of information that the data bring points out to the need for balance among the modes within the matrix, by attenuating the predominance of road transportation, which has contributed to the increase of logistics costs and environmental damage, and by searching for a greater use of waterways and a better use of railway transportation of cargo and passengers, mainly the latter in urban areas.

For a country as big as a continent and with a rich soil, air transportation needs greater support, with a more attractive commercial exploitation, and other modes, such as pipeline, could be an important investment in the exploitation of wealth and, together with the other modes, in raising our Gross Domestic Product (GDP). On the other hand, due to the extension and great importance of the road network in the country, there is a need to increase the number of paved roads and to conserve the existing roads.

Finally, there is a need to invest in decarbonization policies in big urban centers, with the reduction of motorization (powered by the burning of fossil fuels) and measures to encourage the use of public transportation, preferably harnessed by renewable energy (solar, nuclear energy and natural gas, for instance) and active transport (walking and cycling). 
(2009-2014), seguidos em queda em 2016 e 2017, ano de piores resultados, com retomada de melhores resultados em 2018 e 2019 (elevação média de 11\%).

Para uma compreensão mais purada da evolução do setor é importante avaliar o número de passageiros e carga transportados. O Gráfico 15.5 apresenta esses dados e permite verificar que o crescimento do número de passageiros se assemelha ao crescimento do número de voos de 2010 a 2012, porém, a partir de 2013, quando se apresenta a retração da oferta de voos, como observado no Gráfico 15.4, o número de passageiros continua aumentando até 2015 , com queda em 2016, e recuperação de demanda em 2017, 2018 e 2019, de maneira crescente, tanto em voos nacionais quanto em voos internacionais, com descongestionamentos, melhorando o ambiente de negócios dos grandes centros e a qualidade de vida dos seus residentes.

Na parte de carga aérea movimentada, o Gráfico 15.6 se apresenta com comportamento que acompanha relativamente o Gráfico 15.4, de oferta geral de voos. No entanto, a predominância de demanda de carga é muito maior para voos internacionais, mantendo-se a demanda de carga doméstica relativamente estável, com queda nos anos de maior retração de carga aérea, em 2016.

Pode-se perceber que o mercado de transporte de carga, em termos de comportamento geral de flutuação da curva, se parece muito mais próximo ao comportamento da curva de oferta de voos; porém, em termos de tipificação de oferta de voos, se domésticos ou internacionais, a evolução de passageiros transportados se assemelha mais com a de oferta de voos; sendo no caso de cargas aéreas a demanda internacional predominante.

\section{Considerações finais}

Os sistemas de transportes sempre foram elementos estratégicos no processo de desenvolvimento econômico social dos países. Portanto, seus indicadores são importantes para a análise do próprio processo de desenvolvimento e para o planejamento de ações e políticas públicas. A primeira informação que os dados trazem conduz à necessidade de maior equilíbrio da matriz de divisão modal, seja por atenuar a hegemonia do transporte rodoviário, que tem contribuído para a elevação dos custos logísticos e danos ambientais; a busca de maior utilização das hidroviais e de melhor utilização do transporte ferroviário para o transporte de carga e de passageiros, principalmente, este último nas áreas urbanas.

Para um país de dimensões continentais e de solo rico, o transporte aéreo precisa de maior apoio, tornando-se sua exploração comercial mais atrativa e, o uso de ou- 
Investing in sustainable mobility is vital for reducing traffic accidents and traffic jams, improving business environments in big cities and improving the quality of life of their residents.

\section{References}

ANUÁRIO DA INDÚSTRIA AUTOMOBILÍSTICA BRASILEIRA 2017. São Paulo: Associação Nacional dos Fabricantes de Veículos Automotores - Anfavea, 2017. Available from: <http://www.virapagina.com.br/anfavea2017>. Cited: Jan 2020.

ANUÁRIOESTATÍSTICO AQUAVIÁRIO 2019. Brasília, DF: Agência Nacional de Transportes Aquaviários - Antaq, [2020]. Available from: <http://web.antaq. gov.br/anuario/>. Cited: Jan 2020.

BOLETIMESTATÍSTICO [DACONFEDERAÇÃONACIONALDOSTRANSPORTES]. Brasília, DF: CNT, Feb. 2019. Available from: <https://www.cnt.org.br/ boletins>. Cited: Jan 2020.

DADOS e estatísticas. Brasília, DF: Agência Nacional de Aviação Civil - Anac, 2019. Available from: <https://www.anac.gov.br/assuntos/dados-eestatisticas>. Cited: Apr 2020

EVOLUÇÃO do transporte ferroviário de cargas. Brasília, DF: Agência Nacional de Transportes Terrestres, 2017. Available from: <http://portal.antt.gov.br/ index.php/content/view/15884.html>. Cited: Jan 2020.

Translated by: Gisele Flores Caldas Manhães 
tros modos de transporte, como o dutoviário, poderia ser importante investimento na exploração comercial de nossas riquezas e, em conjunto com os demais modos, na elevação do nosso Produto Interno Bruto (PIB). Por outro lado, em virtude da extensão da malha rodoviária no País, sendo o transporte de maior importância, há necessidade de ampliar o número de vias pavimentadas e a manutenção das vias existentes.

Por fim, há necessidade de investir em políticas de descarbonização nos grandes centros urbanos, com a diminuição de motorização pela queima de combustíveis fósseis e de aplicação de medidas de incentivo ao uso dos transporte públicos coletivos, de preferência, movidos à energia renovável (solar, nuclear e à gás natural, como exemplos) e aos transportes ativos (caminhadas e ciclismo). O investimento em mobilidade sustentável é vital para a diminuição de acidentes de trânsito, congestionamentos, melhorando o ambiente de negócios das grandes cidades e meIhorando a qualidade de vida de seus residentes.

\section{Referências}

ANUÁRIO DA INDÚSTRIA AUTOMOBILÍSTICA BRASILEIRA 2017. São Paulo: Associação Nacional dos Fabricantes de Veículos Automotores - Anfavea, 2017. Disponível em: <http://www.virapagina.com.br/anfavea2017>. Acesso em: jan. 2020.

ANUÁRIO ESTATÍSTICO AQUAVIÁRIO 2019. Brasília, DF: janAgência Nacional de Transportes Aquaviários - Antaq, [2020]. Disponível em: <http://web.antaq.gov.br/ anuario/>. Acesso em: jan. 2020.

BOLETIM ESTATÍSTICO [DA CONFEDERAÇÃO NACIONAL DOS TRANSPORTES]. Brasília, DF: CNT, fev. 2019. Disponível em: <https://www.cnt.org.br/boletins>. Acesso em: jan. 2020.

DADOS e estatísticas. Brasília, DF: Agência Nacional de Aviação Civil - Anac, 2019. Disponível em: <https://www.anac.gov.br/assuntos/dados-e-estatisticas>. Acesso em: abr., 2020.

EVOLUÇÃO do transporte ferroviário de cargas. Brasília, DF: Agência Nacional de Transportes Terrestres, 2017. Disponível em: <http://portal.antt.gov.br/index.php/ content/view/15884.html>. Acesso em: jan. 2020. 
Tabela 15.1 - Extensão das malhas viárias do País - 2019

Table 15.1 - Extension of transportation networks in Brazil - 2019

\begin{tabular}{cc}
\hline $\begin{array}{c}\text { Especificação/ } \\
\text { Item }\end{array}$ & $\begin{array}{c}\text { Extensão das malhas viárias }(\mathrm{km}) / \\
\text { Extension of transportation network }(\mathrm{km})\end{array}$ \\
\hline
\end{tabular}

Malha rodoviária/Road network

Federal/Federal

Pavimentada/Paved

Não pavimentada/Unpaved

10375

Estaduais Transitórias, Estaduais e Municipais/

1486938

Temporary State Roads, State and Municipal Roads

Pavimentada/Paved

Não pavimentada/Unpaved

1339100

Rede Planejada/Planned Network

157309

Malha ferroviária/Railway network

Nacional/National

30485

Concedida/Granted

29074

Malha hidroviária/Waterway network

Rede fluvial nacional/National river network

41795

Vias utilizadas economicamente/Economic exploited waterwc

19464

Fonte/Source: Boletim estatístico [da Confederação Nacional dos Transportes]. Brasília, DF: CNT, fev. 201 Disponível em/Available from: <https://www.cnt.org.br/boletins>. Acesso em: jan. 2020 /Cited: Jan. 2020.

Nota/Note: Até fevereiro de 2019/Note: Until February 2019. 


\section{Tabela 15.2 - Dados gerais do transporte ferroviário - 2017 \\ Table 15.2 - General data of railway transportation - 2017}

\begin{tabular}{|c|c|c|}
\hline Concessionárias/ & $\begin{array}{l}\text { Carga transportada } \\
\text { (mil toneladas) (tu)/ }\end{array}$ & Locomotivas/ \\
\hline Concessionary railways & $\begin{array}{l}\text { Transported freight } \\
\text { (thousand tonnes) }\end{array}$ & Locomotives \\
\hline
\end{tabular}

$\begin{array}{cc} & \text { Carga Transportada } \\ \text { Vagões/ } & \mathrm{x} \text { KM útil (mil } \\ \text { Freight } & \text { toneladas)(tku)/ } \\ \text { cars } & \begin{array}{c}\text { Transported freight } \mathrm{xkm} \\ \text { (thousand tonnes) }(\mathrm{tku})\end{array}\end{array}$

América Latina Logística

Malha Norte S.A

859

142

3847

1325

América Latina Logística

Malha Oeste S.A

277

45

831

40

América Logística Malha

Paulista S.A

438

276

5515

359

América Latina Logística

Malha Sul S.A

1079

364

9525

664

Estrada de Ferro Carajás

14089

307

Ferrovia Paraná Oeste S.A

31

15

504

14

Estrada de Ferro Vitória a

Minas

11042

318

18738

6386

Ferrovia Centro-Atlântica

S.A.

1681

578

17593

1014

Ferrovia Norte-Sul Tramo

Norte

Ferrovia Tereza Cristina

S.A.

17

443

Transnordestina

Logística S.A

MRS Logística S.A.

Fonte/Source: Evolução do transporte ferroviário de cargas. Brasília, DF: Agência Nacional de Transportes Terrestres, 2017. Disponível em/Available from: <http://portal.antt.gov.br/index.php/content/view/ 15884.html>. Acesso em: jan. 2020/Cited: Jan. 2020.

Nota: até janeiro/Note: Until january. 
Tabela 15.3 - Movimento de carga, por tipo de navegação - 2011-2019

Table 15.3 - Cargo transportation by modal of navigation - 2011-2019

\begin{tabular}{|c|c|c|c|}
\hline \multirow{2}{*}{$\begin{array}{l}\text { Anos / } \\
\text { Years }\end{array}$} & \multicolumn{3}{|c|}{ Movimento de carga $(1000 \mathrm{t}) /$ Cargo movement $(1,000 \mathrm{t})$} \\
\hline & $\begin{array}{l}\text { Longo curso / } \\
\text { Deep sea }\end{array}$ & $\begin{array}{c}\text { Cabotagem / } \\
\text { Cabotage }\end{array}$ & $\begin{array}{c}\text { Outras navegações / } \\
\text { Others }\end{array}$ \\
\hline 2011 & 657469 & 192612 & 37322 \\
\hline 2012 & 670543 & 197410 & 36446 \\
\hline 2013 & 684196 & 205225 & 39931 \\
\hline 2014 & 713629 & 211754 & 43499 \\
\hline 2015 & 753977 & 210579 & 43748 \\
\hline 2016 & 743462 & 213716 & 45654 \\
\hline 2017 & 804673 & 222445 & 60689 \\
\hline 2018 & 825831 & 231065 & 65839 \\
\hline 2019 & 794754 & 240306 & 69412 \\
\hline
\end{tabular}

Fonte/Source: Anuário estatístico aquaviário 2019. Brasília, DF: Agência Nacional de Transportes Aquaviários, [2020]. Disponível em/Available from : <http://web.antaq.gov.br/anuario/>. Acesso em: jan. 2020/Cited: Jan. 2020.

\section{Gráfico 15.1 - Matriz de transporte de cargas, por modalidades - Brasil - 2019 \\ Graph 15.1 - Matrix of cargo transportation by mode - Brazil - 2019}

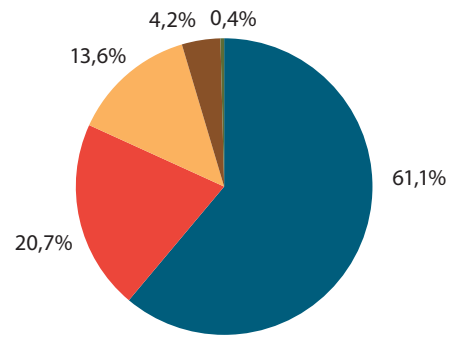

Rodoviário

Road
Ferroviário

Rail
Aquaviário

Waterway
Dutoviário

Pipeline
Aéreo

Air

Fonte/Source: Boletim estatístico [da Confederação Nacional dos Transportes]. Brasília, DF: CNT, fev. 2019. Disponível em/Available from: <https://www.cnt.org.br/boletins>. Acesso em: jan. 2020/Cited: Jan. 2020. Nota: Até agosto de 2019./Note: Until August 2019. 


\section{Gráfico 15.2 - Habitantes por autoveículo em alguns países - 2001/2015}

Graph 15.2 - Inhabitants per vehicle in selected countries - 2001/2015

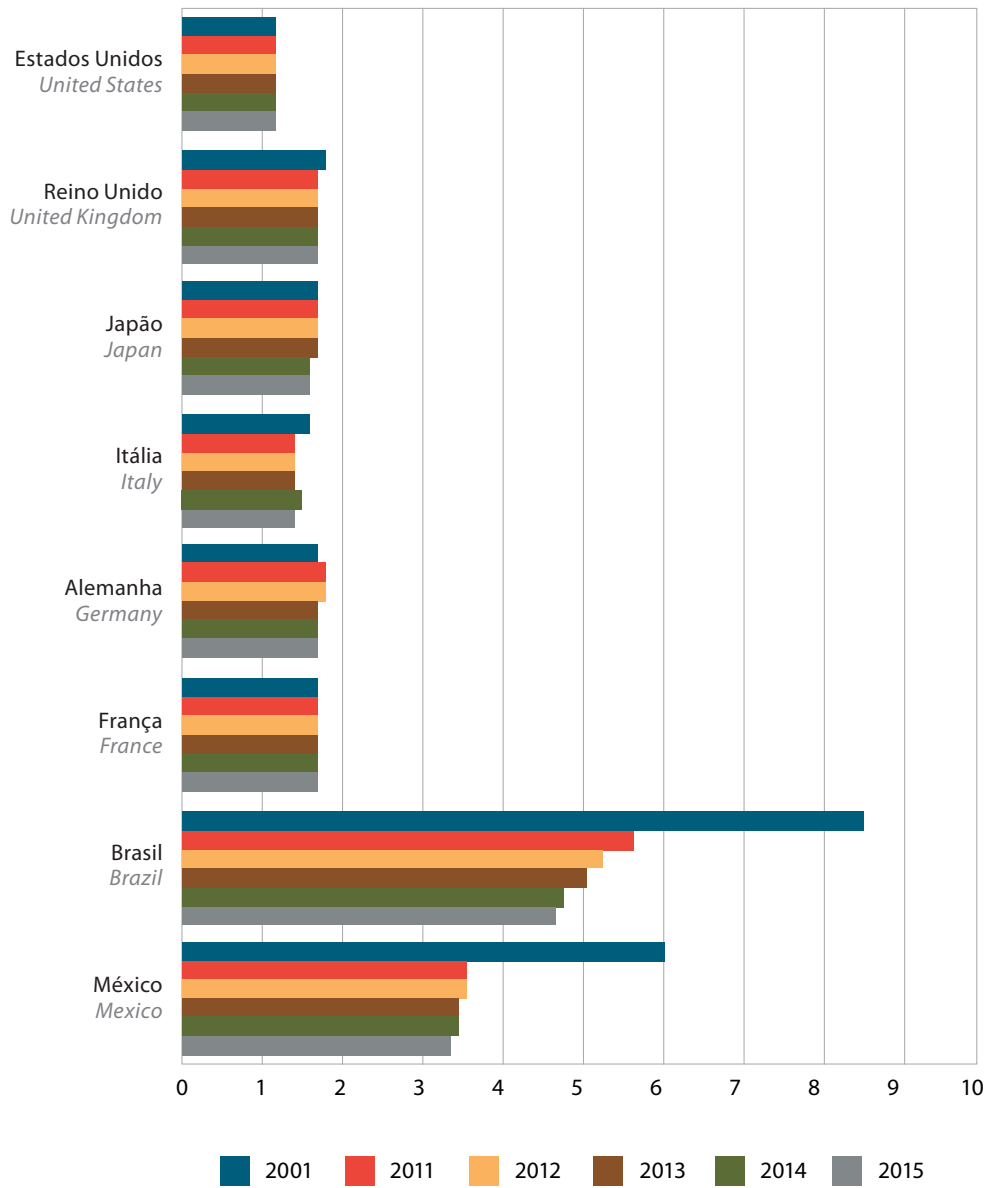

Fonte/Source: Anuário da indústria automobilística brasileira 2017. São Paulo: Associação Nacional dos Fabricantes de Veículos Automotores, 2017. Disponível em/Available from:

<http://www.virapagina.com.br/anfavea2017>. Acesso em: jan. 2020/Cited: Jan. 2020. 
Gráfico 15.3 - Movimento de carga, por tipo de navegação - 2011-2019

Graph 15.3 - Cargo transportation by modal of navigation - 2011-2019

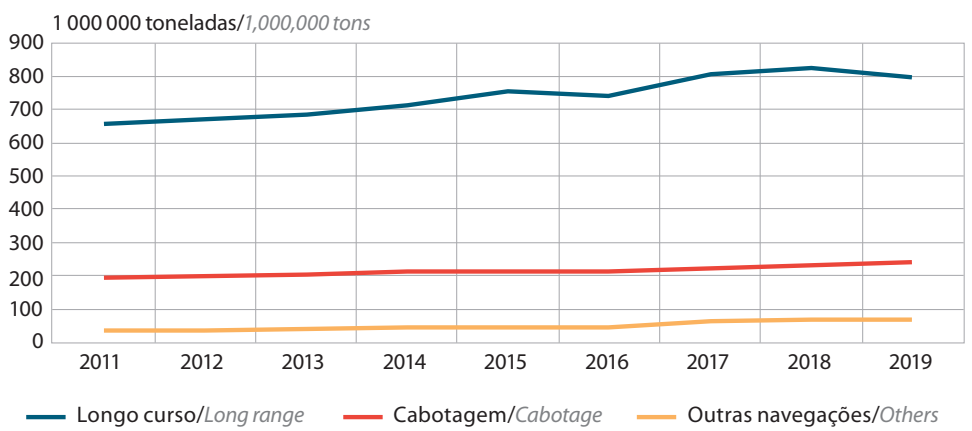

Fonte/Source: Anuário estatístico aquaviário. Brasília, DF: Agência Nacional de Transportes Aquaviários, [2020]. Disponível em/Available from: <http://web.antaq.gov.br/anuario/>. Acesso em: Fev. 2020/Cited: Feb. 2020.

\section{Gráfico 15.4 - Evolução da quantidade de voos - 2010-2019}

Graph 15.4 - Evolution of the number of flights - 2010-2019

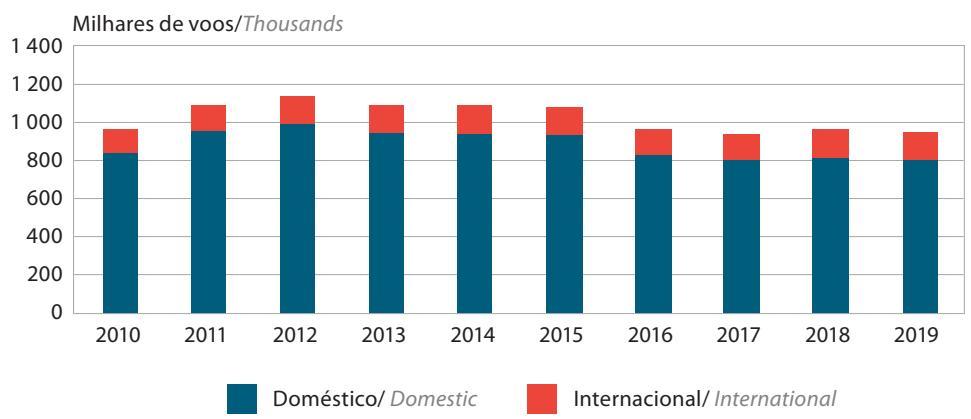

Fonte/Source: Agência Nacional de Aviação Civil (ANAC). 


\section{Gráfico 15.5 - Evolução da quantidade de passageiros transportada 2010-2019}

\section{Graph 15.5 - Evolution of the number of passengers transported - 2010-2019}

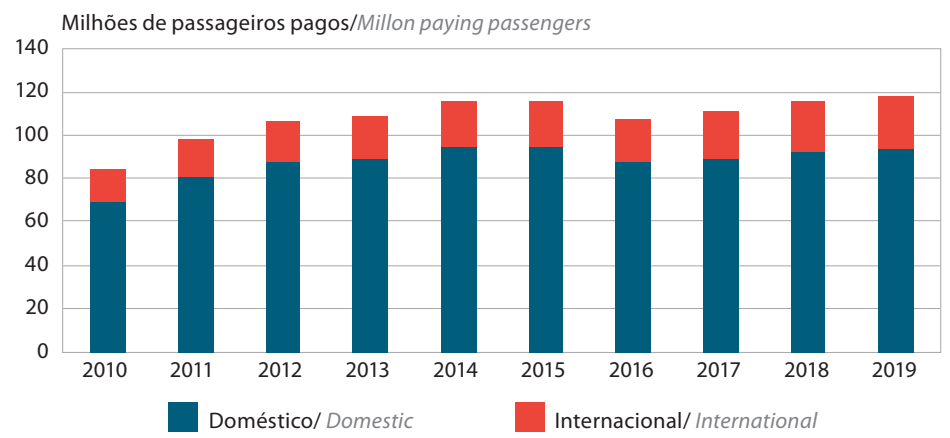

Fonte/Source: Agência Nacional de Aviação Civil (ANAC).

\section{Gráfico 15.6 - Carga aérea transportada - 2010-2019}

Graph 15.6 - Air cargo transported - 2010-2019

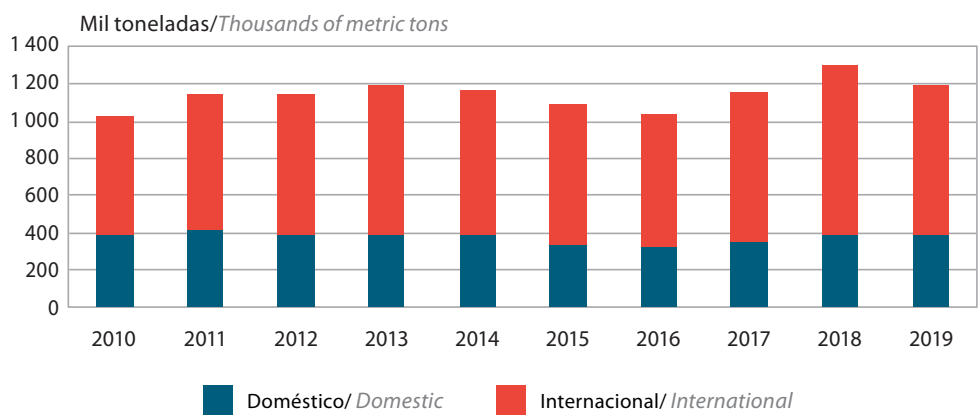

Fonte/Source: Agência Nacional de Aviação Civil (ANAC). 